\title{
Challenges in Translating Rhetorical Questions in the Holy Qur'an: A Comparative Study
}

\author{
Hadeel M. Al-Smadi \\ Department of English Language and Translation, Applied Science Private University, Amman, Jordan
}

\begin{abstract}
Rhetorical questions in the Holy Qur'an are one of the most critical devices in argumentation and persuasion. This study aims at shedding light on the linguistic challenges encountered by seven Qur'an translators in translating rhetorical questions in the Holy Quran into English. The sample of this study included fifteen rhetorical questions selected based on specific criteria from different Surahs in the Holy Qur'an. The translations of the seven Qur'an translators were then analyzed and discussed based on the linguistic approach as a theoretical framework. The study revealed that Qur'an translators tend to use semantic translation rather than pragmatic one in rendering the Qur'anic rhetorical questions into English to maintain the rhetorical features of the Holy Qur'an. Furthermore, the study showed that Qur'an translators convey only some of the illocutionary forces that are embedded in such questions.
\end{abstract}

Index Terms-Arabic, English, rhetorical questions, Qur'an translation

\section{INTRODUCTION}

Translating the Holy Qur'an is one of the biggest challenges that translators face. Al-Abbas \& Haider (2020) state that translation is not merely replacing words of the SL by their equivalent in the TL because Arabic and English have different cultural heritage (Catford, 1965). In addition, the process of translation becomes heftier when the text has a sensitive nature like the Holy Qur'an.

The field of rhetoric in the Holy Qur'an is a complicated area of investigation since performative utterances require special attention from the translator to convey their pragmatic meaning and intended effect. One of the types of performative utterances is rhetorical questions. Studying rhetorical questions in the Holy Qur'an is a very distinguished topic simply because few studies tackled this issue because of the sensitive nature of these questions. Rhetorical questions have the same form as ordinary questions, but they do not seek an answer. Also, they have more functions in Arabic than in English. Thus, some translators of the Holy Qur'an encounter linguistic challenges in translating the Qur'anic rhetorical questions into English. This study is a modest attempt to overcome the main linguistic challenges faced by some translators of the Holy Qur'an.

This study investigates the linguistic challenges of translating the rhetorical questions encountered by seven translators of the Holy Qur'an selected based on directionality and religious background, namely: Abedl Haleem, AlHilali, Dawood, Yusuf Ali, Rodwell, Arberry, and Pickthal. It also discusses the degree of adequacy in translating fifteen Quranic rhetorical questions translated into English based on the perspective of functional equivalence.

This study derives its significance from the fact that English and Arabic are linguistically and culturally remote languages. There are few studies that tackled rhetorical questions in the Holy Qur'an in English, and this study is significant since it compares the adequacy of the translations performed by the seven mentioned translators. Furthermore, this study uses a qualitative approach rather than quantitative and analyzes data in light of the linguistic approach. Thus, it fills a gap in the literature of translation studies.

In order to fulfill the purpose of the study, the current study will attempt to answer the following questions:

1. What are the main functions of the rhetorical questions used in the Holy Qur'an?

2. What are the main challenges of translating Qur'anic rhetorical questions that Ali, Abdel Haleem, Rodwell, Arberry, Al-Hilali, Pickthal, and Dawood encountered?

3. What are the adequate strategies for translating the Qur'anic rhetorical questions?

\section{LITERATURE REVIEW}

\section{A. Rhetorical Questions}

Linguists have presented many definitions for the rhetorical questions. Snell- Hornby (1974, p.727) defines the rhetorical question as one "asked for the sake of effect, to impress people, no answer being needed or expected." Similarly, Ba'albaki (1992) defines the rhetorical question as:

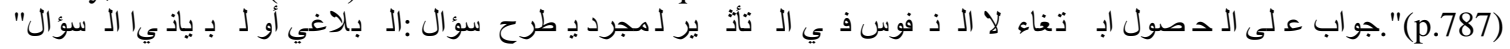

"Rhetorical question: is a question addressed to acquire an effect in the minds of the human beings rather than seeking an answer." 
Richards and Schmidt (2002, p.459) define the rhetorical question as "a forceful statement which has the form of a question but which does not expect an answer.' i.e., the rhetorical question is an interrogative structure but does not seek information. The speaker has some purpose in his mind, either to give a command or to make a statement indirectly.

In Arabic, the interrogative structure can be built by using particles or nouns. There are two primary particles, which

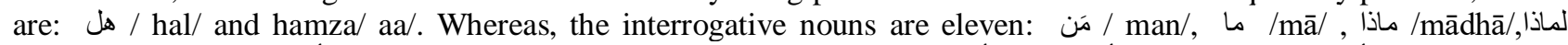

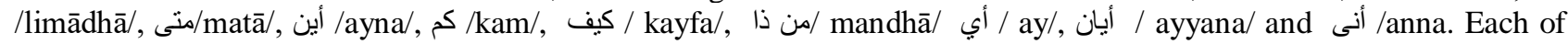
these has its own function in the Arabic questions (Al- Ghalayeni, 1978).

According to Yusef (2000), rhetorical questions in Arabic have the following fourteen meanings: التفاخر (boasting), التقرير (assertion), التمني (wishing), التهنبط (indicating impatience), التوبيل والتعظيخ (intimidation and exaggeration),

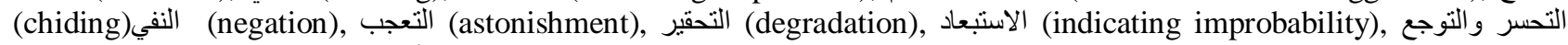
(lamentation and wailing), التقريع (scolding).

However, in English, questions can either be open or closed. It depends on the type of reply they expect. i.e., Yes/ No questions expect affirmation or negation, but Wh- questions expect an answer from an open range of responses (Azar, 1989). According to Larson (1984), the speaker may resort to using the rhetorical questions in English to achieve one of the following purposes: to make a suggestion, to show rebuke, to emphasize, to introduce a new topic, to exhort, to show surprise, to invite, to show politeness or to criticize.

\section{B. QUR'AN TRANSLATION}

Equivalence could be a fuzzy notion with two levels according to theorists. Each level has its proponents and opponents. At the micro-level, i.e., word level, Catford (1965. p.20) defines translation as "the replacement of textual material in one language (source language) by equivalent textual material in another language (target language)." Similarly, Bell (1991. pp. 5-6) (cited in As-Safi, 2011) defines translation equivalence as "the expression in another language (or the target language) of what has been expressed in another, source language, preserving semantic and syntactic equivalence." However, Snell- Hornby (1995) claims that Catford's definition is too general because languages like English and Arabic are linguistically and culturally remote languages.

At the macro level, i.e., text level, Hatem (1997.p.4) states that:

translation equivalence can be adequately established only in terms of criteria related to text type membership, and in the light of how these criteria inform the kind of compositional plan (structure) and the way a text is made internally cohesive (texture).

On the other hand, Koller (1995) mentions certain conditions to achieve equivalence. These conditions are historicalcultural conditions, linguistic- textual, and extra-linguistic factors, including the language of the ST and stylistic and aesthetic contextual properties.

Syntax, Semantics, and Pragmatics differ from one language into another, especially in the case of Arabic and English since each of them has belonged to a particular linguistic family (Al-Khalafat \& Haider 2022). Thus, according to Larson (1984), there are no complete synonyms within the same language, and there is no exact equivalence between words of languages. i.e., complete or total correspondence at any level is impossible, forcing the translator to make some changes in the ST to produce a smooth, natural, and idiomatic translation in the TL.

In the case of the Holy Qur'an, the target text may include new structural, textual, and rhetorical features to produce an acceptable and effective translation in the TL. The main reasons behind the emergence of these features in the TL are the connotative meaning and the semantic voids of the original text (House, 1973). In addition, due to the sensitive nature of the text, Qur'an translation is a unique case of non-equivalence in inter-textual translation (Lefevre, 1975). Thus, in order to create the same effect of the original text in the TL reader, the translator should accept a certain degree of loss in order to convey the message (Abdul-Raof, 2001).

There are two opinions regarding the translatability of the Holy Qur'an. The first opinion is that translators can transfer the meaning of the Holy Qur'an from Arabic into any foreign language. For example, followers of the prophet Mohammad interpreted the Holy Qur'an during his life, but the output of this process is not considered as a substitution of the original text; it is just an interpretation of the Qur'anic words (Murata \& Chittick, 1995). This type of translation is acceptable among Muslim scholars. However, the second type of translation is that which produces another version of the Holy Qur'an in a foreign language, to be as an alternative of the Holy Qur'an. This type of Qur'an translation is rejected by all Muslim scholars since there is no complete and total equivalence for the Holy Qur'an at all levels (AlGhazali, 1991). According to Al- Ghazali (1991), any attempt to translate the Qur'an is just an interpretation of the meaning of the words. i.e., the Arabic Qur'an is the only Qur'an. Whereas Christians consider that Bible is Bible even if it is written in different languages (Murata \& Chittick, 1995).

The Latin language is the first European language that the Holy Qur'an translated into. It was done under the instruction of Petrus Venerabilis, Abbot of Clugny. However, the first Qur'an in the English language was Alexander Ross's translation in 1648. There are many translations of the Holy Qur'an into English performed by Muslim and nonMuslim translators nowadays, such as Yusuf Ali, Taqi-u-din, Asad, Abedl Haleem (Muslims), Rodwell, Dawood, and Arberry (non- Muslims).

\section{Empirical Studies}


Mousa (1995) studies the translation of rhetorical questions from Arabic into English. The research data in her study is drawn from three primary sources: The Holy Qur'an, literary works, and daily newspapers. Mousa (1995) discusses the best approaches and strategies for translating rhetorical questions from Arabic into English. She points out that there is no best approach for translating the Arabic rhetoric since the Arabic language characteristics differ in many aspects from English ones. The translation of rhetorical questions depends on the type of the text, situational context, and the intuition of the translator. In addition, She suggests the eclectic approach to translate the rhetorical questions. She presents four primary levels to analyze the rhetorical questions. These levels are the syntactic level, the semantic level, the pragmatic level, and the aesthetic level. Mousa (1995) concludes that the majority of Qur'anic translators ignore these levels and focus on the denotative meaning (the dictionary meaning) rather than the connotative meaning (the shades of the meaning).

However, Al-Malik (1995) studies the translation of the pragmatic meaning of the performative utterances in the Holy Qur'an. He discusses the five types of performative utterances; imperative, negative, interrogative, vocative and wish. In his study, a quantitative research design is adopted in collecting data, and a linguistic approach is used as a theoretical framework. Moreover, Al-Malik (1995) evaluates the translation of five English translators of the Holy Qur'an, namely: Asad, Dawood, Taqi-u-din, Yusuf Ali, and Arberry. His assessment of translations is based on the situational context and general coherence. He concludes that not all the secondary functions of the rhetorical questions are problematic, but eight of them could be challenging; improbability, fascination, negative imperative, scorn, exaltation, wish, affirmation, and disaffirmation. In addition, Al-Malik (1995) suggests some strategies for translating the informative utterances in the Holy Qur'an, where he focuses on the importance of transferring both the locutionary force and illocutionary force from Arabic into English.

Khalil (2011) studies the secondary functions of the Qur'anic rhetorical question, both in Arabic and English. Also, she focuses on investigating the role of the translator in analyzing these functions before starting a translation to convey adequate meaning. Khalil (2011) applies this study to the Holy Quran, literature, and everyday language. The sample of this study consists of sixty rhetorical questions taken from different Surahs, Najeeb Mahfoo's works: Zuqaq Al-madq and Al-lis wa Al-Kilaab, and Shakespeare's $18^{\text {th }}$ sonnet. The Qur'anic rhetorical questions are translated by Arberry and Ali. However, the examples taken from literature and everyday language are translated by the researcher herself. She relies on a qualitative approach in collecting data from different resources mentioned earlier. She discusses in detail the secondary function of the rhetorical questions such as exclamation, strong assertion, introductory function, rebuke, giving a command, threatening, wishing, blaming, or stating a known fact. Khalil (2011) concludes that the functions of the rhetorical question in Arabic differ from English due to the fact that English and Arabic are linguistically and culturally remote languages. In addition, translating the rhetorical question into English is a problematic issue since it has locutionary and illocutionary forces (speech act theory). Also, she finds out that the translator should have a good knowledge of the functions of the rhetorical questions in both languages.

Similarly, Alnaeim (2015) finds out that the functions of the rhetorical question in Arabic are more complicated than English ones. In addition, she suggests some techniques in order to convey the adequate meaning of the rhetorical questions, such as using particles. In her study, Alnaeim (2015) focuses on the different functions of Arabic Qur'anic rhetorical questions and English ones and their impact on the translation of the Holy Qur'an. The sample of her study consists of ten Qur'anic rhetorical questions translated by Muhammad Taqui-ud-Din Al-Hilali and Muhammad Muhsen Khan and collected by a qualitative approach from different Surahs. She uses Al- Tahreer wa Al- Tanweer interpretation for Ibn Ashoor to determine the function of each rhetorical question, and she analyzes data according to the pragmatic analysis.

After reviewing the literature, the current study finds some gaps in the previous studies. Most of the studies conducted on the Qur'anic rhetorical questions use a quantitative method. However, this study will use a qualitative method that focuses on the meaning and analyzes sensitive issues. Also, there is no room for the researcher's prejudgment utilizing this approach. The previous studies tackled the rhetorical questions in general, while the current study will compare Qur'an translations performed by Yusuf Ali, Abdel Haleem, Rodwell, Arberry, Al-Hilali, Pickthal, and Dawood in light of the linguistic approach. Thus, this study is significant and fills a gap in the literature of translation studies.

\section{Methodology}

This section explains the methodology followed in conducting the current study. It starts with a description of the data selected, followed by a description of data analysis and a theoretical framework.

\section{A. Data Source and Sample of the Study}

The sample of this study consists of fifteen Qur'anic rhetorical questions selected randomly from different Surahs in the Holy Qur'an translated by seven translators selected on the basis of directionality. i.e., whether they are native speakers like Abdel Haleem, Dawood, and Al-Hilali or non-native speakers like Ali, Rodwell, Arberry, and Pickthal and on the base of religion, i.e., whether they are Muslims like Ali, Al-Hilali, Pickthal, Abdel Haleem, and Rodwell or non-Muslims like Dawood and Arberry.

B. Method of the Study 
Data is collected from different Surahs and verses of the Holy Qur'an as the following:

- Collecting a list of interrogative sentences that occur in the Holy Qur'an.

- Classifying the interrogative sentences into genuine or rhetoric according to their purpose, whether seeking an answer or not.

- Determining the function of each rhetorical question by referring to Tafsir Al-Tabari, Tafsir Ibn- Katheer, and Tafsir Al- Zamakhshari.

- $\quad$ Selecting only fifteen rhetorical questions to analyze according to their pragmatic functions.

\section{Data Analysis}

In this study, the researchers followed the research process outlined below.

After selecting the topic, five steps are involved in collecting and analyzing data. These are the following:

Step1: Categorizing the selected rhetorical questions according to their pragmatic functions.

Step2: Giving the translations of the verse translated by the seven translators according to their religion, starting with Muslim translators (Abedel Haleem, Yusuf Ali, Al-Hilali, and Pickthal), then non- Muslims (Rodwell, Dawood, and Arberry).

Step3: Analyzing these translations based on the linguistic approach.

Step4: Assessing the adequacy of translations done by seven Qur'an translators.

Step5: Determining the strategies used to achieve the pragmatic function in these questions.

TABLE 1

CATEgorizing OF THE ANALYZED DATA

\begin{tabular}{|c|c|}
\hline Function & The Number of Rhetorical Questions \\
\hline Exclamation & 4 \\
\hline Wishing & 3 \\
\hline Disaffirmation & 3 \\
\hline Threatening & 2 \\
\hline Giving Command & 1 \\
\hline Strong Assertion & 2 \\
\hline
\end{tabular}

\section{Theoretical Framework}

The current study relies on the linguistic approach since it deals with the meaning of the rhetorical questions in the Holy Quran, whether semantic or communicative. Newmark (1981, p.39) states that,

communicative translation attempts to produce, on its readers, an effect as close as possible to that obtained in the original, while semantic translation attempts to render, as closely as the semantic and structures of the second language allow, the exact contextual meaning of the original.

In other words, the semantic approach deals with the literal meaning of the text, but the communicative approach deals with the intended meaning beyond the text. i.e., pragmatics studies what speakers do with words, whereas semantics studies what words mean. The researcher will analyze the data in terms of how the meaning transferred precisely into English to maintain the rhetorical meaning by discussing the translated texts in terms of the characteristics of the translation types.

\section{RESULTS AND DISCUSSION}

This section is devoted to the findings of the selected Qur'anic rhetorical questions translated by seven translators, namely: Ali, Abdel Haleem, Rodwell, Arberry, Al-Hilali, Pickthal, and Dawood. The findings are presented according to the functions of these questions as determined by Tafsir Al-Tabari, Tafsir Ibn- Katheer, and Tafsir Al- Zamakhshari. Then, they are followed by a discussion for each rhetorical question, including analyzing the translations and determining the best strategies to achieve the purpose of these questions.

\section{Results: Functions}

The analysis of data showed six functions of the rhetorical questions. These functions include:

\section{A. Exclamation التعجب}

One of the secondary meanings of the rhetorical questions used in the Holy Qur'an is Exclamation. Although the exclamation is interrogative in form, it has a pragmatic meaning of exclamatory assertion (Al-Malik, 1995). It is used to express surprise, astonishment, or any other strong emotion.

Example 1: 
TABLE 2

SAMPLE OF EXCLAMATORY RHETORICAL QUESTIONS AND THEIR TRANSLATIONS

\begin{tabular}{|c|c|}
\hline The Arabic Text & 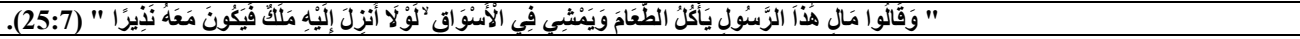 \\
\hline Abdel Haleem & $\begin{array}{l}\text { "They also say, 'What sort of messenger is this? He eats food and walks about in the marketplaces! Why has no } \\
\text { angel been sent down to help him with his warnings?" (2004, p. 227). }\end{array}$ \\
\hline Yusuf Ali & " And they say: ' What sort of a messenger is this, who eats food and walks through the streets?" (1990, p.1034). \\
\hline Al-Hilali & $\begin{array}{l}\text { " And they say: ' Why does this messenger (Muhammad) eat food, and walk about in the markets (like } \\
\text { ourselves)?" (1993, p.528). }\end{array}$ \\
\hline Pickthal & $\begin{array}{l}\text { "And they say: What aileth this messenger (of Allah) that he eateth food and walketh in the markets? Why is not } \\
\text { an angel sent down unto him, to be a warner with him." }(2011, \text { p.112). }\end{array}$ \\
\hline Rodwell & "And they say, "What sort of apostle is this? He eateth food and he walketh the street" (1909, p. 159). \\
\hline & " They also say: ' $\underline{\text { How } \text { is }}$ it that this apostle eats and walks about the market-squares?" (1990, p.253). \\
\hline Arberry & ay, 'What ails this messenger that he eats food, and goes in the markets?" (1991, p.364). \\
\hline
\end{tabular}

The Interpretation of the Verse

By referring to Tafsir Al-Tabari (2005), Tafsir Ibn- Katheer (1999), and Tafsir Al- Zamakhshari (1392 AH), this verse was revealed to Prophet Mohammad after he had met the unbelievers of Mecca. The speakers in this verse are Abu Jahl and his host, al-Nadr and his host, and Umayyah Ibn Khalaf and his host. When Prophet Mohammad invited them to embrace Islam, they rejected his invitation, and they made many objections about why this messenger (of Allah) eateth (food) like they do, and why an angel is not sent down to him as evidence that he is the messenger of Allah. They asked these questions to express their exclamation and surprise.

\section{Discussing the Translations}

As table (2) shows, the seven translators seek to render this verse in a correct grammatical form. The main challenge of translating Qur'anic rhetorical questions encountered by the seven translators is whether to use a semantic translation, i.e., literal translation to be faithful to the ST and maintain the original form, or to use a pragmatic translation, i.e., idiomatic translation to convey the illocutionary force that is embedded in the rhetorical question (Newmark,1981).

In this example, translators tend to use Wh- question form to render the Arabic rhetorical question rather than using the Yes/No question. The Arabic particle "م" is rendered by different Wh- particles, such as what, Why, and How.

The most striking result that emerged from the data is that all translators resort to using the semantic translation to render this question because the exclamatory meaning of the rhetorical question is used in both languages, Arabic and English. According to the linguistic approach, semantic translation is so biased to the ST structure, and it seems possible that these results are there due to the sensitive nature of the text to maintain the rhetorical aspects of the Holy Qur'an. Therefore, translators did not render this rhetorical question into a statement.

Translations of Abdel Haleem, Ali, Rodwell, Arberry, and Pickthal, are very strong since they convey the illocutionary force of the rhetorical question by using some exclamatory elements, such as the relative clauses "that and who". Although they translate the question into interrogative forms, the translators convey the indirect meaning of the question, and it is obvious that the question does not seek an answer. Abdel Haleem's translation could be considered the adequate one since he uses the exclamation mark as a strong indication of the Qur'anic pragmatic meaning. However, Pickthal and Rodwell tend to use archaic words, such as aileth and walketh, to preserve the same level of formality included in the ST. On a par with Abdel Haleem, Yusuf Ali tends to use one of the translation strategies, adding footnotes at the bottom of a page to explain the implicit meaning of the question. This footnote is,

This another objection: 'He is only a man like us: why is not an angel sent down, if not by himself, at least with him?' The answer is: angels would be of no use to men as Messengers, as they and men would not understand each other. And if angles came, it might cause more confusion and wonder than understanding in men's minds. Cf xxi.7-8; xxvii, 94-95. The office of an angle is different. A teacher for mankind is one who shares their nature, mingles in their life, is acquainted with their doings, and sympathizes with their joys and sorrows (Ali,1990, p.1034).

On the other hand, translations of Al-Hilali and Dawood might be semi adequate because they might confuse the TL reader. Al-Hilali used the Wh- particle "why" in his translation to change the rhetorical question into a real one. In addition, the lack of exclamatory elements and the use of question marks at the end of his translation could lead to misunderstanding.

\section{B. Wishing التمني}

As table (1) shows, the second meaning of the rhetorical questions used in the Holy Qur'an is Wishing. It is used to express the speaker's hope and desire toward some situations that are different from those that exist.

Example 2: 
TABLE 3

SAMPLE OF WISHING RHETORICAL QUESTION AND ITS TRANSLATIONS

\begin{tabular}{|c|c|}
\hline The Arabic Text & 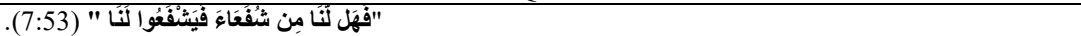 \\
\hline Abdel Haleem & "Is there anyone to intercede for us now?" (2004, p. 98). \\
\hline Yusuf Ali & "Have we no intercessors now to intercede on our behalf?" (1990, p.413). \\
\hline Al-Hilali & " Now are there any intercessors for us that they might intercede on our behalf?" (1993, p.233). \\
\hline Pickthal & "Have we any intercessors, that they may intercede for us?" $(2011, \mathrm{p} .47)$. \\
\hline Rodwell & "Shall we have any intercessor to intercede for us" $(1909, \mathrm{p} .270)$. \\
\hline Dawood & "Will no one plead on our behalf?" (1990, p.113). \\
\hline Arberry & "Have we then any intercessors to intercede for us?". (1991, p.149). \\
\hline
\end{tabular}

\section{The Interpretation of the Verse}

By referring to Tafsir Al-Tabari (2005), Tafsir Ibn- Katheer (1999), and Tafsir Al- Zamakhshari (1392 AH), this verse is talking about the situation of the unbelievers when they will be led to the fire on the Day of Resurrection. This day that they were forgetful of it. At this time, they will be remorseful and start to wish that they had an intercessor who could intercede them.

\section{Discussing the Translations}

As table (3) shows, the seven translators tend to use the Yes/ No question form to render the Arabic rhetorical question. The Arabic particle so is used by the unbelievers to express the meaning of hope rather than seeking information. It is rendered in the TT by different Yes/No particles, such as Is, Have, Shall and will. Moreover, the seven translators, whether native speakers or non-natives, transfer the Arabic question into an English one, preserving in this way the Arabic style.

Translations of Dawood and Yusuf Ali could be very strong since they tend to use the negative, which gives the question a strong indication that it is not a real question and does not seek information.

Translations of Abdel Haleem, Al-Hilali, Pickthal, and Rodwell could be semi adequate since they tend to use a form that is considered a straightforward question. Thus, for non-native speakers who are not familiar with Arabic rhetoric, they cannot understand the indirect meaning of this verse unless the translators resort to using specific strategies to convey the meaning.

However, Arberry's translation could be considered semi- adequate since he uses "then" to express some elements of wish. Moreover, in their translations, Yusuf Ali and Rodwell tend to express the verse's implicit meaning by adding a footnote after the translation. The following is Ali's footnote:

If those without Faith want to wait and see what happens in the Hereafter, they will indeed learn the truth, but it will be too late for them to profit by it then. All the false ideals and false gods which they put their trust upon will leave them in the lurch. If they thought that the goodness or greatness of others would help them, they will be undeceived on the day when their personal responsibility will be enforced. There will be no salvation except on their own record. How they will then wish that had another chance! But their chance will be gone (Ali,1990, p.413).

By contrast, Rodwell resorts to adding the following short footnote to convey the pragmatic meaning of the verse "The fulfillment of its promises and threats" (Rodwell, 1909, p.280).

\section{Disaffirmation الانكار}

One of the most important meanings of the rhetorical question is disaffirmation since it is used to express a refusal to grant the truth of a statement or such a thing.

Example 3:

TABLE 4

SAMPLE OF DENIAL DISAFFIRMED RHETORICAL QUESTION AND ITS TRANSLATIONS

\begin{tabular}{|c|c|}
\hline The Arabic Text & 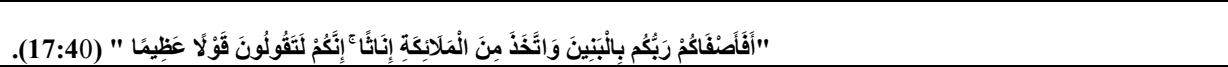 \\
\hline Abdel Haleem & $\begin{array}{l}\text { "What? Has your Lord favoured you people with sons and taken daughters for Himself from the angles? } \\
\text { What a monstrous thing for you to say!" }(2004, \text { p. 177). }\end{array}$ \\
\hline Yusuf Ali & $\begin{array}{l}\text { "Has then your Lord, (O pagans) preferred for you sons, and taken for himself from among the angles } \\
\text { daughters?" (1990, p.788). }\end{array}$ \\
\hline Al-Hilali & $\begin{array}{l}\text { "Has then your Lord (O pagans of Makkah) preferred for you sons, and taken for himself from being the } \\
\text { angles daughters?" (1993, p.414). }\end{array}$ \\
\hline Pickthal & $\begin{array}{l}\text { "Hath your Lord then distinguished you (O men of Mecca) by giving you sons, and hath chosen for Himself } \\
\text { females from among the angles? Lo! verily ye speak an awful word!" (2011, p.87). }\end{array}$ \\
\hline Rodwell & $\begin{array}{l}\text { "What! hath your Lord prepared sons for you, and taken for himself daughters from among the angles? } \\
\text { Indeed, ye say a dreadful saying." }(1909, \text { p.168). }\end{array}$ \\
\hline Dawood & $\begin{array}{l}\text { "What! Has your Lord blessed you with sons, and Himself adopted daughters from among the angles?" } \\
(1990, \text { p.206). }\end{array}$ \\
\hline Arberry & $\begin{array}{l}\text { "What, has your Lord favoured you with sons and taken to Himself from the angles females?". (1991, } \\
\text { p.278). }\end{array}$ \\
\hline
\end{tabular}




\section{The Interpretation of the Verse}

By referring to Tafsir Al-Tabari (2005), Tafsir Ibn- Katheer (1999), and Tafsir Al- Zamakhshari (1392 AH), in this verse, God responds for liars unbelievers who claim that angels are God's daughters and preferred sons are for men of Mecca.

\section{Discussing the Translations}

Table (4) compares the seven translations of this verse. As shown, Abdel Haleem, Rodwell, Dawood, and Arberry tend to use Wh- question form whereas Ali, Al-Hilali, and Pickthal tend to use the Yes/ No question form. Using the latter one changes the question from being rhetorical into being close to the real one. However, adding "then" to the translation conveys some aspects of disaffirmation.

On the other hand, Using Wh- question in general and "What" in particular followed by an exclamation mark is considered a strong indication that this question carried a pragmatic meaning rather than a semantic one.

Abdel Haleem's translation and Dawood's translation could be the adequate ones since they use the exclamation

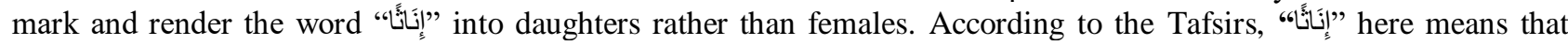
angels are God's daughters. By contrast, in his translation, Pickthal resorts to using archaic words, such as Hath, Lo, and ye.

Ali, Al-Hilali, and Pickthal resort to illustrating the meaning of the verse by using one of the translation strategies, which is paraphrasing, such as adding "O pagnas" and "O men of Mecca". Moreover, Ali uses another translation strategy which is the addition of footnotes. He adds the following one:

Insistence on true worship also means the exclusion of false worship or worship derogatory to God. In circles where daughters were despised, and even their lives had to be protected by special legislation, what could have been more dreadful than ascribing daughters to god?

\section{Suggested Strategies and Signals}

The results of this study show that there is no best approach to translate the rhetorical questions in the Holy Qur'an. Thus, translators can use one of the two types of translation according to the linguistic approach: semantic or pragmatic. If the translators tend to use semantic translation, they have to use the strategy of elaboration and explication, whether by adding footnotes at the bottom of the page or paraphrasing within the text. On the other hand, if the translators tend to use the pragmatic translation, they have to use the conversion strategy. i.e., render a question into a statement. The findings of this study agree with Mousa's (1995) findings, which showed that there is no significant approach to translating the rhetorical questions. It depends on the type of the text, situational context, and the translator's intuition.

Overall, these results indicate that Qur'an translator should be fully aware of the secondary meaning of the rhetorical questions in both Arabic and English to be able to determine which type of translation, semantic or pragmatic, is appropriate to render such questions since rhetorical questions in Arabic are more complicated than in English. The current study's findings are consistent with those of Khalil (2011) and Alnaeim (2015). In addition, translators should take the following signals into consideration to make the intended meaning of the rhetorical questions clearer in the TT, and this goes with what Mona Baker argues for Universals: explication and implication:

1. Adding certain words that are not existed in the ST, such as "O", "then" and "also".

2. Adding some punctuation marks in the TT.

3. Using brackets to explain specific terms.

4. Adding footnotes.

\section{CONCLUSION}

Based on the analysis of the data, the current study revealed that rhetorical questions have six main functions: which are exclamation, wishing, disaffirmation, giving a command, threatening and strong assertion, and this answered the first question of the study which is "What are the main functions of the rhetorical questions used in the Holy Qur'an?"

Comparing the types of questions in Arabic with English ones answered the second question of the current study and showed that the main challenges of translating Qur'anic rhetorical questions are whether to render the rhetorical question into a question or into a statement, (i.e., whether to explicit what is implicit or not). In addition, the study focused on the best strategies to make these pragmatic meanings of the questions explicit.

Regarding the third question, which is "What are the adequate strategies of translating the Qur'anic rhetorical questions?" the study pointed out that there are different strategies to translate them, such as the strategy of elaboration and explication, whether by adding footnotes at the bottom of the page or paraphrasing within the text.

In conclusion, the current study has demonstrated that translating Qur'anic rhetorical questions into interrogative forms may not convey the illocutionary forces of the source text leading to misunderstanding. However, the results have shown that transferring the Arabic rhetorical questions into English ones may convey some and not all of the illocutionary forces that are embedded in them. Also, it has indicated that since the Holy Qur'an is considered the sea of rhetoric, the functions of Arabic rhetorical questions differ somehow from English ones. Thus, Qur'an translators should have good knowledge of the functions of rhetorical questions in English as well as in Arabic. Furthermore, the study has shown that the afore-mentioned translators tried to compensate for the translation loss by using different strategies, such as explication and elaboration. It has also attributed these results to the sensitive nature of the Holy Qur'an and the difficulty in rendering the speech of Allah, which is full of rhetoric. 
The limitations of this study can be summarized as:

1. The sample of this study is selective and limited to fifteen Qur'anic rhetorical questions due to time limitations.

2. The methodology of this study is qualitative in nature.

\section{REFERENCES}

[1] Abdul-Raof, H. (2001). Qur'an Translation. London and New York: Routledge, Taylor \& Francis.

[2] Abedel Haleem, M. (2004). The Qur'an. New York, US: Oxford University Press.

[3] Al-Abbas, L. \& Haider, A.(2020). Evaluating the Accuracy and Consistency in Rendering Qur'anic Terms with Overlapping Meanings into English. Al-Bayan: Journal of Qur'an and Hadith Studies, 18 (2), 111-137. DOI: https://doi.org/10.1163/22321969-12340083

[4] Al-Ghalayini, M. (1978). Jaami' Ad-Duroos Al-Arabiyyah. Lebanon, Beirut : Al-Maktabah al-'Asriah

[5] Al-Ghazali, M. (1991). Kayfa Nata'amal ma'a Al-Qur'an. USA: Al-Ma'had Al-Alami Lil-Fikr Al-Islami.

[6] Al-Hilali, T. \& Khan, M. (1993). The Noble Qur'an in the English Language. Riyadh: Maktaba Dar Al-Andalus.

[7] Ali, A. (1990). The Holy Qur'an: English Translation of the Meanings and Commentary. Al-Madinah Al-Munawarah: King Fand Holy Qur'an Printing Complex.

[8] Al-Khalafat, L., \& Haider, A. S. (2022). A Corpus-assisted Translation Study of Strategies Used in Rendering Culture-bound Expressions in the Speeches of King Abdullah II. Theory and Practice in Language Studies, 12 (1), 130-142.

[9] Al-Malik, F. (1995). Performative Utterances: Their Basic and Secondary Meanings with Reference to Five English Translations of the Meanings of the Holy Qur'an. (PhD Thesis), Durham University, the United Kingdom. Retrieved on January 25, 2021 from https://core.ac.uk/download/pdf/108168.pdf.

[10] Alnaeim, A. (2015). Rhetorical Questions with Reference to the Glorious Qur'an: Pragmatic Approach (MA Thesis), Sudan University of Science and Technology, Sudan. Retrieved March, 1, 2021 from http://repository.susteck.edu/handle/123456789/12967.

[11] Altabrii, M. (2005). Jamie Albayan Ean Tawii AY Al-Quran. Egypt: Dar Al Maaref.

[12] Al-Zamakhshari, A. (1392 AH). Al-Kashshaaf. Egypt: Mustafa al-Babi al-Halabi Publisher

[13] Arberry, A. (1991). The Koran Interpreted. Oxford: Oxford University Press.

[14] Azar, B. (1989). Understanding and Using English Grammar. New Jersey, US: Prentice Hall Regents.

[15] Ba'albaki, M. (1992). Al-Mawrid: A modern English-Arabic dictionary. Beirut: Dar-El-Ilm Lil-Malayeen.

[16] Bell, R. (1991). Translation and Translating: Theory and Practice. London and New York: Longman. [Cited in As- Safi, A. (2011). Translation Theories Strategies and Basic Theoretical Issues. Amman, Jordan: Dar Amwaj].

[17] Catford, J. (1965). A Linguistic Theory of Translation. London, UK: Oxford University Press.

[18] Dawood, N. (1990). The Koran. London: Penguin Books.

[19] Hatim, B. (1997). Communication Across Cultures: Translation Theory and Contrastive Text Linguistics. Exeter: University of Exeter Press.

[20] House, J. (1973). On the limits of translatability. Babel 19, pp.166-167.

[21] Ibn Kathir, I. (1999). The Exegesis of the Grand Holy Qur'an. Riyadh, Saudi Arabia: Dar Taibah For Publishing \& Distribution

[22] Khalil, G. (2011). On the Translation of Qur'anic Rhetorical Questions into English. Journal of the Faculty of essential Education, 18 (72), 73-87.

[23] Koller, W. (1972). Grundprobleme dcr Ubcrsetzungstheorie: unter besondcrcr Berucksichtigung schwedisch-deutschcr UbcrsetzungsJalle. Berne: Franke.

[24] Larson, M. (1984). Meaning-Based Translation: A Guide to Cross-Language Equivalence. Lanham: University Press of America.

[25] Lefevre, A. (1975). Translating Poetry. Assenl Amsterdam: The Van Gorcum.

[26] Mousa, A. (1995). The translation of rhetorical questions from Arabic into English. (Master's Thesis). Yarmouk University, Amman, Jordan.

[27] Murata, S. \& Chittick, W. (1995). The Vision of Islam. London: I. B. Tauris.

[28] Newmark, P. (1981). Approaches to translation. Oxford: Pergammon press.

[29] Pickthal, M. (2011). The Meaning of the Glorious Qur'an. US: Library licensing, LLC

[30] Richards, J \& Schmidt, R. (2002). Longman Dictionary of Language Teaching and Applied Linguistics. Malaysia: Pearson Education Limited.

[31] Rodwell, J. (1909). The Koran. London \& Toronto.

[32] Snell- Hornby, A. (1974). Oxford Advanced Learner's Dictionary of Current English. Oxford: Oxford University Press.

[33] Snell- Hornby, A. (1995). Translation Studies: An Integrated Approach. Amsterdam/Philadelphia: John Benjamins Publishing Company.

[34] Yusef, A. (2000). Aslubu Al-Istihaam Fi Al-Quran Al-Karim. Damascus, Syria: Al-Ghazali.

Hadeel M. Al-Smadi is a lecturer in the Department of English Language and Translation at the Applied Science Private University, Amman, Jordan. She received her Master's in Translation from Yarmouk University, Irbid, Jordan. Her main areas of interest include Media Translation, Narrative Theory, and Religious Translation. 